\title{
Design of a terahertz CW photomixer based on PIN and superlattice PIN devices
}

\author{
Krozer, Viktor; Eichhorn, Finn
}

Published in:

Joint 31st International Conference on Infrared Millimeter Waves and 14th International Conference on Teraherz Electronics, 2006. IRMMW-THz 2006.

Link to article, DOI:

10.1109/ICIMW.2006.368597

Publication date:

2006

Document Version

Publisher's PDF, also known as Version of record

Link back to DTU Orbit

Citation (APA):

Krozer, V., \& Eichhorn, F. (2006). Design of a terahertz CW photomixer based on PIN and superlattice PIN devices. In Joint 31st International Conference on Infrared Millimeter Waves and 14th International Conference on Teraherz Electronics, 2006. IRMMW-THz 2006. IEEE. https://doi.org/10.1109/ICIMW.2006.368597

\section{General rights}

Copyright and moral rights for the publications made accessible in the public portal are retained by the authors and/or other copyright owners and it is a condition of accessing publications that users recognise and abide by the legal requirements associated with these rights.

- Users may download and print one copy of any publication from the public portal for the purpose of private study or research.

- You may not further distribute the material or use it for any profit-making activity or commercial gain

- You may freely distribute the URL identifying the publication in the public portal 


\title{
Design of a terahertz CW photomixer based on PIN and superlattice PIN devices
}

\author{
Viktor Krozer and Finn Eichhorn \\ Electromagnetic Systems EMI, Ørsted-DTU, Technical University of Denmark, DK-2800 Kgs. Lyngby, Denmark \\ email:vk@oersted.dtu.dk
}

\begin{abstract}
We present the design of a photomixer LO based on standard and superlattice PIN diodes, operating at $1 \mathrm{THz}$. The design is based on a direct integration of a double slot antenna with the PIN device and a suitable matching circuit. The antenna has been designed together with a dielectric lens using Ansoft HFSS EM simulation. The large-signal PIN diode model employed in the work has been improved compared to our previously developed model presented earlier in a $3 \mathrm{THz}$ design. We demonstrate that the antenna characteristic changes drastically with the device in place.
\end{abstract}

\section{INTRODUCTION}

We consider simulation experiments of photomixers for LO THz signal generation using PIN structures. PIN type devices, such as the UTC device have demonstrated good high frequency performance and higher output powers as compared to the LT GaAs mixers at $\mathrm{THz}$ frequencies. In this paper we concentrate on the integration issues of such devices with both broadband and resonant antenna structures. Our study is based on 3-D EM simulation and large-signal device simulation [1], [2].

\section{InTEGRATED Photomixer ANTENNA STRUCTURES}

The devices employed in the study were generic PIN diodes or the recently introduced NIPNIP supperlattice photomixer devices. The large-signal model of these devices has been implemented into a circuit simulator using VHDLA. The device structure is provided in fig. 1 integrated with a resonant antenna. The simulations without device show a good radiation pattern with a radiation efficiency around $93 \%$ using a $\mathrm{Au}$ metal thickness of $0.5 \mu \mathrm{m}$ and a $7.7 \mathrm{~dB}$ larger main beam compared to backside radiation. At $1 \mathrm{THz}$ the antenna gain is $7.5 \mathrm{~dB}$.
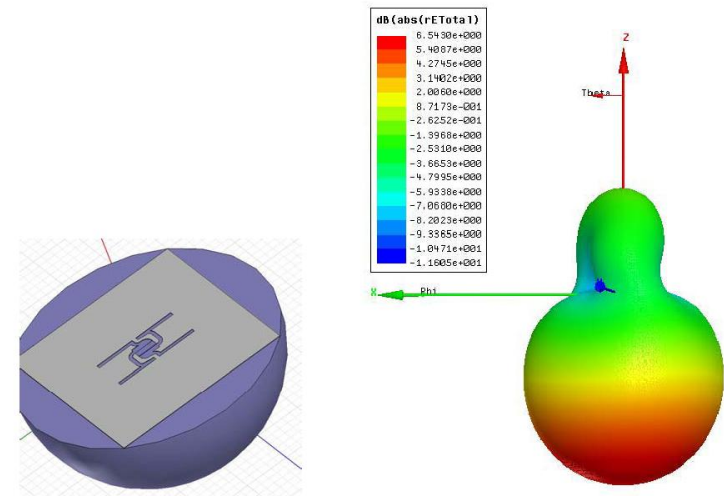

Figure 1. Double-slot antenna with device placed on a Si half sphere and its radiation pattern without device.
Introducing the device simulations show a tilted main beam angle of about 10 degrees, as indicated in fig.2 (left). The back lobe radiation is still low compared to the main beam radiation, but the backside radiation decreases to 6.6 $\mathrm{dB}$. The antenna gain is $5.73 \mathrm{~dB}$. The decreased antenna efficiency is due to the mismatch between the device impedance and antenna structure impedance.
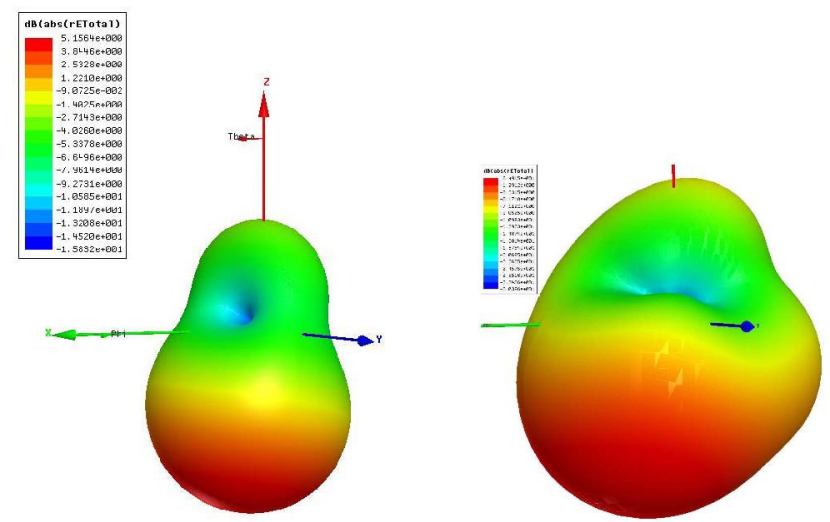

Figure 2. Antenna radiations pattern after placing the device into the antenna structure (left) and for the splitted plane antenna including the device.

The "splitted plane" structure for DC-biasing of the device is proposed and simulations show a degraded radiation pattern (fig. 2 right). The main beam radiation to backside radiation improves to $8.6 \mathrm{~dB}$ with a radiation efficiency of $87 \%$ compared to the simulations obtained for the single plane antenna including device. The main beam, however, is tilted about 30 degree away from the main axis. The splitted antenna structure is not optimized and has to be fine tuned for a better a radiation pattern into the lens.

\section{CONCLuSions}

A design study of a $\mathrm{THz}$ photomixer has been demonstrated. The emphasis in the paper is on the integration of the photomixer device with a resonant antenna. It is shown that due to the large device geometry and performance of the integrated antenna is deteriorating considerably.

\section{REFERENCES}

[1] C. Fritsche and V. Krozer, "Modelling of thz power generation based on ultra-fast pin photodiodes," in 16th Intern. Symp. On Space Terahertz Technology - ISSTT 2005, Gothenborg, May2-4 2005, May 2005.

[2] C. Fritsche and V. Krozer, "Large-signal pin diode model for ultra-fast photodetectors," in 2005 Proc. European Microwave Conf., Nov 2005. 